\title{
NEW WATER ACT IN POLAND \\ - CHANGES AND DILEMMAS
}

\section{NOVÝ ZÁKON O VODE V POLSKU - ZMENY A DILEMY}

\author{
Edward PIERZGALSKI*
}

\section{Introduction}

Water resources are of exceptional importance for social and economic development and the state of the natural environment. Because they are unevenly distributed over time and in space, the use of water resources was, is and probably will be often a source of acute conflicts, including local and transboundary conflicts. In order to avoid or limit them, various rules were introduced sometime in the form of legislative documents, whose history goes back several thousand years. A lot of legal documents related to water management are related to agriculture, which results from the strict dependence of agricultural production on water conditions. This is understandable because in the world, as much as $80 \%$ of water is used in agriculture. One of the first written legal regulations in this respect was the Hammurabi Code developed in the $18^{\text {th }}$ century $\mathrm{BC}$. This code is widely known for precisely defining the rights and obligations related to the use of water, and especially for drastically high penalties applied in the event of neglecting the obligation to maintain irrigation equipment in good condition by their owners.

In later times, regulations regarding water resources were included, among others in civil Roman law. In medieval legal

\section{Abstract (EN)}

The article presents the reasons and goals of the new Water Act development, which was supposed to replace amended many times the 2001 Water Act. A new Water Act has been approved 1 July 2017. The main aim of new Water Act is an achievements the objectives of the EU Water Framework Directive and other EU directives related to water management. The most important change of new Water Act is the establishment of a new water management organization in Poland, for which since January 1, 2018 is responsible the State Water Enterprise Polish Waters. The second new fundamental change is the introduction of nine water management financial instruments. Water services fees are one of them. The mechanism for determining the amount of these fees was one of the most debatable problems when adopting this legislative document. The article also presents the voices criticizing the detailed introduced solutions, including changes in investment of water infrastructure and their maintenance in agriculture.

\section{Keywords (EN)}

water act, Poland, water management documents there are already detailed indications regarding water association. In various regions of the world and in individual countries, the water management documents take into account local conditions related to political, economic, social and climate changes, which forces periodic changes to legal acts. A significant development of water legislation with an attempt to codify it occurred in Europe in the $19^{\text {th }}$ century (Austrian law, 1869)(1). The codification of Prussia from 1913 was a model for other later legislative documents ${ }^{(2)}$, including the first Water Act (1922) in Poland after recovery independence (1918). It was a relatively small document (35 pages), but it was in force after a few amendments until 1962. The next Water Acts were adopted in Poland by the legislative authorities in 1974 and 2001

After Poland's accession to the European Union (2004) the 2001 Water Act has been amended many times, among other things, due to the need to adapt it to the European Union legislative documents. The number of amendments was so great that it was decided to develop a completely new Water Act. Such decision was influenced by complaint of the European

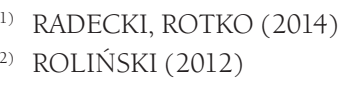

\section{Abstrakt (SK)}

Predkladaný príspevok predstavuje dôvody a ciele pre prijatie nového zákona 0 vode, ktorý by mal nahradit' mnohokrát novelizovaný vodný zákon z roku 2011. Nový zákon o vode bol schválený 1. júla 2017. Hlavným zámerom tohto zákona je dosahovanie ciel'ov Európskej rámcovej smernice 0 vode a iných európskych smerníc, ktoré sa týkajú vodného manažmentu. Najdôležitejšou zmenou, ktorú zákon prináša, je založenie novej organizácie v Polsku, ktorá sa bude zaoberat' vodným manažmentom. Od 1. januára 2018 je touto organizáciou Štátny vodohospodársky podnik polské vody. Druhou významnou zmenou je zavedenie deviatich finančných nástrojov vodného manažmentu. Jedným z nich sú poplatky za vodohospodárske služby, pričom mechanizmus stanovenia výšky týchto poplatkov predstavoval jeden z najdiskutovanejších problémov. Príspevok obsahuje tiež kritiku zavedených riešení, vrátane zmien vodnej infraštruktúry a jej údržbu v polnohospodárstve.

\section{Klúčové slová (SK)}

zákon o vode, Pol'sko, vodný manažment

Forest Research Institute, Sękocin Stary, Poland 
Commission of the European Union for the lack of full transposition of the Water Framework Directive EU to Polish legislative documents. The first allegations were sent by the European Commission in 2008, the second warning in 2010, and after the third in 2012 the EC brought the case to the Court of Justice of the European Union, which on June 30, 2016 issued a judgment unfavorable for Poland, forcing it to take appropriate measures. Lack of reaction could cause the blocking of funds from the European Union's operational programs for the years 2014-2020 for planned water investments in Poland.

Work on the new Water Act started in 2012. The work lasted until 2015 when the final draft of the Water Act was adopted by the government. However, the parliament did not debate it because after the elections in 2015, there was a change of government and parliament. The new authorities in a relatively short time presented a new draft of the Water Act. Their aim was to remove the flaws of the Water Act of 2001, which were accused of dispersing the competences of water management in various institutions and the lack of an appropriate financing system and financial instruments. The second important objective of the new Water Act was to create a legal basis for the reform of water management that would meet the requirements and achieve the objectives of the Water Framework Directive and other EU directives related to the shaping, use and protection of water resources ${ }^{(3)}$.

The new Water Act was enacted in 2017 and entered into force on January 1, 2018 ${ }^{(4)}$. The Water Act 2017 introduces new legal, organizational, financial and technical solutions regarding flood and drought protection, water services and water management, while maintaining some of the existing ones. The importance and significance of Water Act 2017 is demonstrated by the fact that its adoption required changes to over 40 national laws and implementation of 7 water-related directives EU. In addition to the most important directives: Water Framework Directive (2000), Nitrates Directive (1991) and Flood Directive (2007), the new Water Act also implemented five others EU directives concerning:

- municipal wastewater treatment (1991),

- bathing water quality management (2006),

- protection of groundwater against pollution and deterioration (2006),

- the framework for action on the marine strategy (2008),

- environmental quality standards in the field of water policy (2008).

Some of the changes and new solutions introduced in the Water Act 2017 may be considered for use in other countries, of course after their verification in practice.

\section{Structure of Water Act}

The new Water Law was announced in the Journal of Laws of 2017 item 1566. It is a document (216 pages) consisting of 13 sections, 39 chapters and 574 articles. A detailed list of sections

\footnotetext{
GAJDA (2018)

(4) Water Act. 2017. Journal of Law (Dziennik Ustaw) No. 1566 Act 20 July 2017
}

and chapters is given in Table 1 .

Among the sections of this Water Act, attention is drawn to the extended section III devoted to water protection. This is understandable, as almost all of the above-mentioned EU directives relate to activities connected with water quality. The sections VI, VII, VIII and IX are crucial for the reform being introduced, as they illustrate the new organizational system of water management and instruments of its financing. Other sections cover issues also covered in earlier water laws, but of course they have been adapted to the concept of the implemented reform.

\section{Major changes in the Water Law}

The new Water Law introduces many new solutions in water management, of which the main areas of change are:

- organization of water management,

- water ownership,

- water services,

- water law permits.

In addition, the new legal bases for water management contain a number of changes compared to existing ones, including those concerning, inter alia, water protection and water drainage.

\section{III.1 Organizational changes}

Water Act introduces a completely new organization of water management in relation to the previous one. On January 1, 2018, an administrative unit was established and, at the same time, a state legal entity, the State Water Enterprise Polish Waters responsible for water management in Poland. At the beginning of January 2018, the Department of Water Resources of the Ministry of Environment was liquidated, and the Polish Waters were located in the Ministry of Maritime Economy and Inland Navigation. Also, local government units dealing with, among others, waters important for agriculture (Voivodship Offices for Land Reclamation and Water Facilities) were liquidated, and part of their staff was employed in the Polish Waters.

The activity of Polish Waters is managed by the President of Polish Waters, who has four Deputy Presidents for:

- protection against flood and drought,

- water services,

- water environment management,

- economy and organization.

Three of the above-mentioned Vice-Presidents are managed by the departments comprising the following internal units:

- Department of Protection Against Flood and Drought with four divisions: Investment, Maintenance, Planning of Flood Protection and Drought, Center for Flood Protection, 


\section{Agrárne}

Table 1: Structure of Water Act 2017

\begin{tabular}{|c|c|}
\hline Section & Chapter \\
\hline \multirow{3}{*}{ I. General rules } & 1. General regulations \\
\hline & 2. Explanations of statutory terms \\
\hline & 3. Water and water bodies \\
\hline \multirow{2}{*}{ II. Use of water } & 1. Use of water and water service \\
\hline & 2. Water used for bathing \\
\hline \multirow{7}{*}{ III. Water protection } & 1. The purpose of water protection and environmental goals \\
\hline & 2. Principles of water protection \\
\hline & 3. Treatment of municipal wastewater \\
\hline & $\begin{array}{l}\text { 4. Protection of waters against pollution by nitrates from agricul- } \\
\text { tural sources }\end{array}$ \\
\hline & 5. Polluting substances \\
\hline & 6. Protection of water intakes and inland water reservoirs \\
\hline & 7. Environmental protection of marine waters \\
\hline \multirow{2}{*}{ IV. Flood risk management and counteracting the effects of drought } & 1. Flood risk management \\
\hline & 2. Counteracting the effects of drought \\
\hline \multirow{2}{*}{ V. Water engineering, drainage and } & 1. Water engineering \\
\hline & 2. Drainage and irrigation irrigation \\
\hline \multirow{5}{*}{ VI. Property management of State Treasury } & 1. Ownership of waters and obligations of their owners \\
\hline & 2. The State Water Enterprise Polish Waters \\
\hline & 3. The financial management of the Polish Waters \\
\hline & 4. Property management of State Treasury \\
\hline & 5. Economic instruments in water management \\
\hline \multirow{4}{*}{ VII. Management of waters } & 1. Planning \\
\hline & 2. Information system for water management \\
\hline & 3. Water management control \\
\hline & 4. Water monitoring \\
\hline \multirow{2}{*}{ VIII. Water Authority } & 1. Minister competent for water management \\
\hline & 2. State services \\
\hline \multirow{5}{*}{ IX. Water permission } & 1. General regulations \\
\hline & 2. Issuing of water permits \\
\hline & 3. Expiration, withdrawal and limitation of the water law permit \\
\hline & 4. Water-legal notification \\
\hline & 5. Water-legal assessments \\
\hline \multirow{4}{*}{ X. Water Association and Levee Association } & 1. Establishment of Water Association and Levee Association \\
\hline & 2. Water Association bodies \\
\hline & 3. Supervision and control over the activities of Water Association \\
\hline & 4. The dissolution of Water Association \\
\hline XI. Compensation liability & 1. Compensation liability \\
\hline XII. Penal provisions & 2. Penal provisions \\
\hline \multirow{2}{*}{$\begin{array}{l}\text { XIII. Changes in regulations, transitional, adaptation and final } \\
\text { provisions }\end{array}$} & 1. Changes in regulations \\
\hline & 2. Transitional, adaptation and final provisions \\
\hline
\end{tabular}


- Department of Water Services with five divisions: Water Permissions, Coordination of Water Management Control, Property management of State Treasury and Cooperation with Water Users, Charges and Measurements, Hydropower,

- Department of Water Environment Management six divisions: Planning in Water Management, Water Programs, Environmental Management, Information System of Water Management, State Hydrological and Meteorological Service and State Hydrogeological Service.

The Deputy President for Economic and Organizational Affairs is responsible for three divisions: Organizational, Information Technology and the Economic.

The structure of the Polish Waters also includes other units: 11 regional water management boards, 50 catchment managements and about 330 water supervisions. A detailed list of their tasks is contained in the Water Act and the Statute of the Polish Waters ${ }^{(5)}$.

An important role in water management is played by the minister competent for water management, who shapes the directions of water policy and oversees the Polish Waters, hydrological and meteorological service, hydrogeological service and service for the safety of damming constructions. The advisory body of the minister will be the State Water Management Council with slightly different competences than the National Council for Water Management still operating until the end of its term.

\section{III.2 Water properties}

The ownership rights in relation to public waters owned by the State Treasury are performed by:

1. Polish Waters - in relation to inland flowing waters and groundwater, excluding inland waterways of special transport importance,

2. minister competent for maritime economy - in relation to territorial sea waters and internal sea waters,

3. minister competent for inland waterways - in relation to inland waterways of special transport importance.

4. national parks have the right to perpetual usufruct in relation to land covered with waters within the borders of the national park.

Polish Waters may also, after obtaining the consent of the minister competent for water management, entrust the execution of ownership rights to waters to the Forest District or a local government unit.

\section{III.3 Water services}

In the works on the Water Law Act, the most controversial was the introduction of a new concept of "water services", in particular the mechanism for setting fees for water services and their size. According to the definition adopted, the water service is the use of waters beyond the scope of general, ordinary and special use of water. The catalog of water services provided in the Water Act is as follows:

(5) KOZA (2018)
- groundwater or surface water intake,

- damming, storing or retaining the groundwater and surface water and using these waters,

- treatment of underground and surface water as well as their distribution,

- collection and treatment of sewage,

- outflow of wastewater to waters or to the ground, including also the outflow of wastewater to water facilities,

- use of water for the purpose of energy, including hydropower,

- outflow of rain or thaw water to open or closed rainwater drainage systems or collective sewage systems within the administrative boundaries of cities,

- permanent drainage of land, object, construction excavation and mining plants, as well as outflow of drainage water to water receiver within the administrative boundaries of cities,

- outflow of water taken and unused into waters or into the ground.

\section{III.4 Fees and penalties}

Water services fees are one of nine water management financial instruments. A novelty is the implementation by the end of 2020 of the obligation to equip (at the cost of the Polish waters) water equipment with the apparatus for measuring the amount of water taken in and measuring the amount of water and sewage outflowed into waters or into the ground.

Fees for water services consist of a fixed fee and a variable fee. The amount of the fixed fee is determined annually by the Polish Waters mainly on the basis of entries in the water permit.

It should be noted that a fixed fee is not payable for water abstraction for agricultural or forestry purposes for irrigation of land and crops as well as for the purpose of rearing and breeding fish. The variable fee depends mainly on the quantity of the amount of water collected or sewage outflowed. In the Water Act, there are a few references to water management in forests. The provisions of Article 274 may be relevant, in which the upper rate for collecting underground water for irrigation for forest purposes by means of pumping equipment was set at about 0,04 EUR per $1 \mathrm{~m}^{3}$.

The Water Law also establishes penalties in the form of socalled fees increased for the provision of water services without a water permit in the amount of 500\% of the variable fee due or for violation of the water permit in the amount of a 10-fold unit variable fee rate. In the absence of a water permit, Polish waters may issue a decision to prohibit the performance of a water service immediately.

\section{III.5 Water permits}

Water rights permits treated as an instrument of water management will be issued by the organizational units of the Polish Waters (regional water management boards and management boards), and not as it was before by local government units, ie by marshals of provinces or poviat starosts.

A new concept of water law agreement has been introduced, which includes the following administrative proceedings leading to: 
- issuing a water law permit,

- acceptance of the water law declaration,

- issuing a water legal assessment,

- issuing a decision to repeal certain prohibitions regarding the use of water or other activities related to water management.

A water permit is necessary, among others on:

- performance of water services,

- special use of water,

- long-term lowering of water level and reclamation of surface and underground waters,

- construction of devices and water structures such as canals, ditches, ponds, water reservoirs.

Obtaining a water permit is necessary before obtaining, among others decisions on building and spatial development conditions, decisions on building permits, road construction projects.

The procedure for issuing water permits and accepting the water-law declaration has not changed. Water-law assessment is a new instrument for water management. Its acquisition is required when planning activities that may affect the achievement of environmental objectives, mainly related to the water quality of water bodies. The positive assessment enables the planned project to be implemented, while the negative assessment requires a specialist justification and consent to the proposed action is the competence of the Polish Waters authorities.

\section{6 Other significant changes}

A lot of attention was devoted in the Water Act to protection of waters against pollution, in particular activities aimed at protection of waters against pollution of agricultural origin, i.e. leading to the requirements of the Nitrates Directive. The current approach based on special activities in the areas particularly exposed has been changed and one action program for the whole country has been established obliging farmers to use the so-called catalogue of good agricultural practices.

Among other changes introduced into the Water Act, the provisions regarding water melioration (drainage and irrigation systems) are relevant for agricultural and forest areas. The definition of water melioration has been changed to the following: "Water melioration consists in regulating water relations in order to improve soil production capacity and facilitate its cultivation." In the current definition, also not completely correct in substance, one of the functions of land improvement was protection against floods in rural areas.

According to the provisions of the Water Law, the realization and maintenance of irrigation and drainage devices belongs to the owner of the land. However, it was envisaged to participate in covering the costs of these works with financial resources from other sources, including public funds with a specific form of payment by farmers in the form of so-called melioration fee. These regulations relate to farmland and, similarly to the Water Law of 2001, there are no specific provisions relating explicitly to the land improvement in forest areas. A further change is the abolition of the existing in the Water Act from 2001, the division into basic melioration facilities financed from the state budget and detailed melioration measures financed by owner with the support of public funds with their partial reimbursement by farmers.

The introduced change may cause negative effects, because drainage or irrigation systems, in order to fulfill their functions properly, must be able to outflow or supply water. For this purpose, mainly watercourses and canals are used in Poland, which were previously classified as basic melioration facilities. According to the current Water Act, regulations concerning the training of rivers and their maintenance do not take into account their key role in the functioning of drainage and irrigation systems. The specifics of water receivers and water supply have been omitted in principle, stating in general that the maintenance of water facilities belongs to their owners and includes an operation, maintenance and renovation in order to preserve their functions, and the costs of maintaining water facilities are attended by those who benefit from them. So if the maintenance costs of so-called watercourses important for agriculture are to burden the owners of the drained land, it can be predicted with a high probability of a rapid degradation process of drainage systems. This problem was probably taken into account, because in one of the article it has been states: "Local government units may incur the costs of investments carried out on waters owned by the State Treasury and the costs of maintaining those waters."

\section{Summary}

The legislative bases of water management are very difficult to codify, due to the varied needs and conflict situations related to water resources. The development and adoption of the existing Water Act, as well as the previous 2001, lasted for many years. Undoubtedly, the new Act meets the requirement to reduce the dispersion of competences in water management.

The transfer of the water management department from the Ministry of the Environment to the Ministry of Maritime Economy and Inland Navigation is a surprise and is assessed differently, however it should be recalled that until 1960 there was the Ministry of Shipping and Water Management from which in 1960 the Central Office of Water Management was separated. It functioned until 1972, when competencies in water management issues were divided into three ministries, mainly the Ministry of Agriculture. In 1983, the Office for Environmental Protection and Water Management was established, which after several subsequent changes was transformed into the Ministry of the Environment. According to the Author's opinion, after the organizational changes, the name of the current Ministry of Maritime Economy and Inland Navigation would be more appropriate to the name of the Ministry of Water Management.

Organizational and substantive changes in the Water Act, which are assessed as revolutionary rather than evolutionary, require a certain period of time for their proper implementation and improvement. This also applies to the operation of Polish Waters. It should be emphasized that water law is a document that should reflect environmental conditions as well as political, economic, social and climatic changes that enforce periodic amendments to legal acts, which is undoubtedly awaited by the new Water Act. 


\section{References}

1. GAJDA M. 2018. New water act - basic thesis. In Water management (in Polish), no. 1, pp. 6-8.

2. KOZA I. 2018. Polish Waters - together for future our waters. In Water management (in Polish) no. 1, pp. 9-20.

3. RADECKI W. ROTKO J. 2014. Basic features of the Czech water law from the Polish Point of view. In Przegląd prawa ochrony środowiska. (in Polish) no. 1. pp. 140-178.

4. ROLIŃSKI M. 2012. Elements of water law in historical development, with particular emphasis on Polish water laws (part I). In Studia Iuridica Lublinensia (in Polish) no. 18, pp. 83-91.

5. Water Act. 2017. Journal of Law (Dziennik Ustaw) No. 1566 Act 20 July 2017 (in Polish).

\section{Contact address/ Kontaktná adresa}

prof. dr hab. Edward Pierzgalski

Forest Research Institute,

Sękocin Stary, Poland,

e-mail: E.Pierzgalski@ibles.waw.pl 